This document was prepared in conjunction with work accomplished under Contract No. DE-AC09-96SR18500 with the U.S. Department of Energy.

This work was prepared under an agreement with and funded by the U.S. Government. Neither the U. S. Government or its employees, nor any of its contractors, subcontractors or their employees, makes any express or implied: 1 . warranty or assumes any legal liability for the accuracy, completeness, or for the use or results of such use of any information, product, or process disclosed; or 2 . representation that such use or results of such use would not infringe privately owned rights; or 3 . endorsement or recommendation of any specifically identified commercial product, process, or service. Any views and opinions of authors expressed in this work do not necessarily state or reflect those of the United States Government, or its contractors, or subcontractors. 
WSRC-STI-2007-00090

Proceedings of PVP2007/Creep-8

2007 ASME Pressure Vessels and Piping Division Conference

July 22-26, 2007, San Antonio, Texas

PVP2007-26370

\title{
TYPE B RADIOACTIVE MATERIAL PACKAGE
}

\section{FAILURE MODES AND CONTENTS COMPLIANCE}

\author{
S. J. Hensel \\ Savannah River National Laboratory \\ Washington Savannah River Co. \\ Aiken, South Carolina 29808 \\ (803) 735-8440, steve.hensel@srnl.doe.gov \\ R. W. Watkins \\ Savannah River National Laboratory \\ Washington Savannah River Co. \\ Aiken, South Carolina 29808 \\ (803) 208-3592, robert.watkins@srs.gov \\ A. C. Smith \\ Savannah River National Laboratory \\ Washington Savannah River Co. \\ Aiken, South Carolina 29808 \\ (803) 725-2943, allen.smith@srnl.doe.gov
}

\begin{abstract}
Type B radioactive material package failures can occur due to any one of the following: inadequate design, manufacture, and maintenance of packages, load conditions beyond those anticipated in the regulations, and improper package loading and operation. The rigorous package design evaluations performed in the certification process, robust package manufacture quality assurance programs, and demanding load conditions prescribed in the regulations are all well established. This paper focuses on the operational aspects of Type B package loading with respect to an overbatch which may cause a package failure.
\end{abstract}

\section{BACKGROUND}

Previous work by the authors examined the regulatory status of Type B package material contents compliance [1]. The emphasis was on evaluating existing regulations and guidance documents. The authors proposed using a graded approach where minor content deviations from the Certified Package contents envelopes could be resolved much like minor manufacture deviations which are controlled during package fabrication (i.e. by the package design agency without involvement of a national competent authority). Content attributes deemed essential to package safety, such as maximum allowed fissile mass or heat load, would be identified in the package Certificate of Compliance $(\mathrm{CoC})$. Transport of contents in excess of these limits would require approval of the national competent authority.

Establishing the basis for the graded approach, that is identifying the content attributes of most interest, necessitates developing a relationship among these attributes and package safety - specifically radiological safety.

II. TYPE B PACKAGE RADIOLOGICAL SAFETY 


\section{A. Shielding}

Three sources of radiation are typically evaluated in Type B pacakges. The first source is simply the radiation emitted by radioactive materials. Radioactive materials emit alpha, beta, gamma and neutron radiation as they undergo radioactive decay. The second source occurs when radiation from the originating isotope can interact within the content materials or with the packaging material to generate radiation. For example, neutron sources are often created by combining plutonium and beryllium. The alpha particles from the plutonium interact with the beryllium to generate the neutrons. The third source comes from fissile material in substantial but subcritical quantities causing multiplication of neutrons which result in an increase in neutron radiation.

The Type B package regulations, 10 CFR 71, provide radiation rate limits during Normal Conditions of Transport for the surface of a package $(200 \mathrm{mrem} / \mathrm{hr}), 1$ meter from the surface of a package $(10 \mathrm{mrem} / \mathrm{hr})$, for the surface of the conveyance $(200 \mathrm{mrem} / \mathrm{hr})$ and 1 meter from the surface of the conveyance $(10 \mathrm{mrem} / \mathrm{hr})$ for exclusive use vehicles. In addition, upon package closure a radiation dose measurement of the package is required for compliance verification, and a survey of the conveyance is required prior to initiating the shipment.

\section{B. Subcriticality}

A nuclear criticality occurs when a sufficient quantity of fissile material in a proper configuration is assembled. The fissile isotopes per DOE G 421.1-1 are U-232, U-233, U-235, Pu-239, Pu-241. Protection against a criticality include: control of fissile mass, control of enrichment (e.g. fraction of U-235 in a uranium content), control of concentration ( often used with solutions), use of poisons (neutron absorbers), and control of moderation (light element materials such as water or graphite). Package limits that protect against a criticality are based upon rigorous calculations whose methodology has been benchmarked against a relatively small set of very precise criticality experiments. In addition, a bias is used in the calculations in order to provide for an acceptable margin of safety.

The Type B package regulations specify that single units, single flooded units and arrays of packages be evaluated during Normal Conditions of Transport. As a result of the array evaluation a Criticality Transport Index is computed. This Index is used to restrict the number of packages which may be shipped on a single conveyance.

\section{Containment}

Containment of the radioactive material is the heart of package design and safety. External loads on the packages are covered by the regulations (e.g. solar heat, cold, drop, puncture, crush, and fire). Internal loads or conditions which could impair containment include pressurization, corrosion or galvanic reactions, excessive heat, and ignition of combustible gases. The containment boundary and closure/sealing area of the package must be adequate at all times.

Containment vessels are designed, fabricated, and inspected per ASME BPVC Section III Division 1 Subsection NB. Rigorous leak tests per ANSI N-14.1 are performed as part of an annual maintenance. Each package upon closure is also leak tested, although not to the standards of the annual test, to ensure adequate assembly.

\section{SINGLE ITEM PACKAGE LOADING}

Loading of single item contents into Type B drum packages is routine within the DOE Complex. For example, the DOE-STD-3013 provides for a container to be used for 50 year plutonium storage, and the 9975 package is certified to transport a single 3013 container. This example will be used to qualitatively evaluate the potential safety concerns with transporting a single content item, namely a 3013 container, in the 9975 package. However, the concepts discussed are generally applicable to other packages.

\section{A. Shielding}

The radiation dose rate on the 3013 will generally be known prior to loading and closure of the 9975. Cans with high neutron dose rates are susceptible to regulatory non-compliance as the 9975 has no neutron shielding. Since the radioactive material has been stabilized prior to packaging, there is little concern about generating secondary radiation during transport which is not already present during package loading. Similarly, minimal subcritical multiplication of neutrons is anticipated during transport than is already present at the time of package closure, even when an array of packages is shipped. Since several 9975 packages are shipped per conveyance the radiation dose rates of the conveyance must be carefully checked to ensure compliance.

\section{B. Subcriticality}

It is very difficult to imagine a situation where a criticality does not occur until the 9975 package is closed and the shipment commences. A criticality event involving overbatch of a single 3013 would likely occur when the overbatch occurs or during staging in the facility where the 3013 is produced. As expected, the fissile mass per 3013 container is strictly controlled. Typically, the total 
content mass is precisely measured using an accurate scale. For the 9975 package there are no special controls involving neutron poisons. The interaction of an array of 9975 containers indicates that no more than 25 can be placed on a single conveyance, even though an infinite array of packages has been shown to remain subcritical. An array of overbatched 3013 containers has not been evaluated.

\section{Containment}

For material packaged in 3013 containers, pressurization, corrosion, and generation of flammable gases have all been thoroughly evaluated. The 9975 has a very robust containment vessel designed to 800 psig per ASME BPVC Section III Division 1 Subsection NB. One source of pressurization would be a sudden change in content temperature such that adsorbed moisture is released. This scenario was evaluated as part of the Hypothetical Accident Conditions. Corrosion is very unlikely to be a concern since the material has been stabilized. Ignition of combustible gases remains an elusive topic for evaluation. Bounding analyses often yield wild estimations of potential hydrogen generation rates and amounts. A comprehensive and reliable model for predicting hydrogen generation does not yet exist [2]. The final area of consideration is heat generation. Isotopes $\mathrm{Pu}-238$ and $\mathrm{Pu}-$ 240 and Am-242 are alpha emitters with relatively high specific activities (especially $\mathrm{Pu}-238$ ). The 9975 is certified for up to 19 watts. The containment vessel and o-ring seal $\left(400^{\circ} \mathrm{F}\right.$ continuous service) have temperature limits. The lead shielding (melting temperature approximately zzzF) and overpack material (degradation temperature approximately $300^{\circ} \mathrm{F}$ ) also have temperature limits. Thermal overbatching is most likely to occur due to assuming an incorrect isotopic distribution. The isotopics are typically measured as part of a broader assay program. In general gross failures, such as at least one order of magnitude, would have to occur in order to exceed critical package temperature limits such as the oring service temperature.

\section{MULTIPLE ITEM PACKAGE LOADING}

Package failures due to loading multiple items are much more likely to occur than failures due to loading single items. Care must be taken to accurately sum quantities such as fissile mass, moderator, heat generation, and radiation dose rates. The certification process requires such an evaluation, however recall that the focus here is on an overbatch occuring during loading where the contents is non-compliant resulting in unforseen interactions among the items. A more complex example of a potential package failure is where materials are loaded together within a package, however at the time of package closure confinement barriers, which are typically not credited during transport, serve to keep the material apart. During transport failure of the confinement barriers occurs and the materials mix. Potential hazards from such mixing include increased radiation, chemical reactions, and nuclear criticality.

\section{A. Shielding}

The potential for additive effects from loading multiple containers which exceed package dose rate limits is worthy of consideration. Not only are primary radiation fields additive, but interactions which lead to secondary radiation must also be considered. This is especially true if the items to be shipped together were not staged together in the facility prior to package loading. The greatest risk could occur if cans of radioactive materials among approved content envelopes are mixed. For example, a package may be certified for two different content envelopes. One for Pu-239 and another one for a $\mathrm{Pu}-\mathrm{Be}$ neutron sources. However, a shipper may incorrectly conclude that material from both envelopes may be shipped together. The subcritical multiplication from the Pu-239 combined with the neutron source could result in a neutron radiation field above the regulatory limits.

\section{B. Criticality}

An overbatch of fissile mass in a shipping package is most likely to occur during loading of multiple items, especially if the items were not staged together in the facility. The fissile mass limits for $\mathrm{Pu}-239$ metal are low enough that it is credible to consider a scenario where two subcritical masses are loaded together in the shipping pacakge. This criticality event would occur nearly instantly during package loading once the items were brought together. Another scenario of interest is an overbatched package that remains subcritical until package flooding occurs.

\section{C. $\underline{\text { Containment }}$}

Containment failure could be facilitated by a thermal overbatch of a package. The shipper must ensure that the heat generation from each of the content items is properly accounted for and summed to a value below the certified limit for the package. Another potential failure scenario is due to reactions among the content items, especially after a convenience can failure. For example, wet or moist plutonium or uranium oxide powder shipped with uranium or plutonium metal could readily lead to hydrogen generation. Again, the problem arises from inappropriately loading together items from different content envelopes (i.e. metal and oxide).

\section{RECOMMENDATIONS}


The qualitative failure analysis presented is intended to identify the most critical content attributes. A graded approach which emphasizes these attributes could be developed and used to form the basis of ensuring package safety through contents compliance. Likewise, a mechanism should be established to allow packaging design agencies to evaluate less critical attributes, similar to the current practice of permitting minor manufacturing deviations to be evaluated by the packaging design agency, without involvement of the national competent authority.

For all package loadings the critical attributes are: stabilized material that is not subject to change (e.g. chemical, physical form) during transport, fissile mass or radioactive material mass, and heat generation. Also, any other credited criticality control (e.g poisons inherent in the contents such as $\mathrm{Pu}-240$ ) is considered to be a critical attribute. For multiple item package loadings evaluation of fissile mass and heat generation requires additional rigor as the materials may be brought together for the first time during package loading. Additionally, care must be taken to ensure the items are within the same approved content envelope. A simple and effective method for protecting against such a failure is to determine the total amount of each radionuclide to be shipped in the same package and compare this value against the limit in the content envelope (e.g. mass of U-235, U-238, Pu-238, Pu239, $\mathrm{Pu}-240, \mathrm{Pu}-241$ and $\mathrm{Pu}-242$ ).

The critical attributes should be identified as package limits by the national competent authority and presented as such in the package certificate of compliance. A listing of non-critical attributes, those used as bounding assumptions in the safety evaluation, should also be provided in the certificate. The package design agency should be allowed to evaluate content deviations of noncritical attributes without formal involvement of the national competent authority.

\section{CONCLUSIONS}

A qualitative evaluation of hypothesized radioactive material package failures due to content non-compliance has been performed to identify content attributes critical to package safety. Both single item and multiple item contents have been evaluated. The authors recommend that the limits for the critical attributes be specifically called out in the package certificate. Limits for other less critical attributes which were used as input to the transportation safety evaluation should be identified in the certificate, however package design agencies should be allowed to evaluate and approve shipment of contents beyond such limits.

\section{ACKNOWLEDGMENTS}

The information contained in this article was developed during the course of work under Contract No. DE-AC09-96SR18500 with the U.S. Department of Energy.

\section{DISCLAIMER}

This document was prepared in conjunction with work accomplished under Contract No. DE-AC09-96SR18500 with the U. S. Department of Energy. DISCLAIMER This report was prepared as an account of work sponsored by an agency of the United States Government. Neither the United States Government nor any agency thereof, nor any of their employees, nor any of their contractors, subcontractors or their employees, makes any warranty, express or implied, or assumes any legal liability or responsibility for the accuracy, completeness, or any third party's use or the results of such use of any information, apparatus, product, or process disclosed, or represents that its use would not infringe privately owned rights. Reference herein to any specific commercial product, process, or service by trade name, trademark, manufacturer, or otherwise, does not necessarily constitute or imply its endorsement, recommendation, or favoring by the United States Government or any agency thereof or its contractors or subcontractors. The views and opinions of authors expressed herein do not necessarily state or reflect those of the United States Government or any agency thereof.

\section{REFERENCES}

1. Hensel, S. J., Watkins, R. W. and Smith, A. C., "Type B Package Radioactive Material Contents Compliance", PVP2006-93375, 2006 ASME Pressure Vessel and Piping Conference, Vancouver, BC, July, 2006.

2. DOE-STD-3013-2004, "Stabilization, Packaging, and Storage of Plutonium Bearing Materials, April, 2004. 